\title{
TRAINER AND TRAINEES MODELING BASED ON COMPLEX INFORMATION APPROACH TO IMPROVEMENT OF TRAINING INFORMATION TECHNOLOGIES AND SYSTEMS
}

\author{
Khodakov V. Ye. - Dr. Sc., Professor, Head of the Department of Information Technologies, Kherson National \\ Technical University, Kherson, Ukraine. \\ Sokolov A. Ye. - PhD, Associate Professor, Associate Professor of the Department of Information Technologies, \\ Kherson National Technical University, Kherson, Ukraine. \\ Veselovskaya G. V. - PhD, Associate Professor, Associate Professor of the Department of Information \\ Technologies, Kherson National Technical University, Kherson, Ukraine.
}

\section{ABSTRACT}

Context. The problem in substantiation for methods on constructing models of trainer and trainees, taking into account the peculiarities of their information activity, is considered. The object for the study were the models of trainer and trainees as participants in information interaction.

Objective. The goal for the work is the solving of the tasks in conceptualization and formalization, aimed at modeling the trainer's subsystem in the framework of information technology for instruction, as well as modeling information flows and information procedures in the model of the trainee's subsystem.

Method. The key components of learning systems and processes are the trainer and trainees. The essential features of information interaction between the instructor and trainees are highlighted. The basis is the concept of the information flow, the specific properties of information flows that are characteristic of learning processes and important for their successful progress are identified. Methods for modeling the key components of the training system as an information system are proposed, such as: the trainer's subsystem, considered from the point of view of the application for learning information technologies; a subsystem of the trainee, represented from the perspective of the use for information flows and information procedures.

Results. The proposed models were implemented programmatically and studied practically in the learning processes as a result of working out the modeling tasks for the trainer and trainees as participants in information interaction.

Conclusions. The conducted experiment confirmed the effectiveness and validity of the concepts and formalisms, the appropriateness for their implementation in information systems, processes and technologies of teaching with the purpose of increasing the processes efficiency on obtaining and practical implementation of information activity models for the trainer and trainees. Further development of research implies the consideration for a wider range of the information activity aspects on the educator and trainees, as well as the corresponding experimental approbations.

KEYWORDS: modeling, trainer, trainee, information, information systems, information processes, information technologies.

\section{NOMENCLATURE}

$A$ is a memory operator;

$A^{-1}$ is an inverse memory conversion;

$A_{0}$ is an initial nondegenerate memory operator;

$\boldsymbol{A}$ is a parameter vector with components $m, s, \theta$;

$\boldsymbol{a}_{\boldsymbol{i}}$ is an $i$-th implementation for the vector of parameters $\boldsymbol{a}$;

$C$ is an assessment scale of learning error;

$C_{i k^{*}}$ are grades obtained for educational trajectories $k^{*}$ of the $i$-th learning stages;

$C_{k i}$ is an estimate obtained for the $\kappa_{i}$-th segment on the $i$-th stage of the learning trajectory;

$\operatorname{dim} X$ is a dimension for a subset of the set $M$ at the input;

$\operatorname{dim} Y$ is a dimension for a subset of the set $M$ at the output;

$f$ is a functor for the operator of signal transformations;

$f^{-1}$ is an inverse transformation functor for $f$;

$f()$ is a function for the signal conversion operator;

$f^{-1}()$ is a reverse signal conversion;

grad is a gradient function designation;

$H_{I} \mathrm{O}$ is an entropy associated with the information process $I$ and the time parameter $t$;

$H_{t=k}()$ is an entropy of the $t=k$ cross-section for a random process describing the information flow $I$;

(C) Khodakov V. Ye., Sokolov A. Ye., Veselovskaya G. V., 2019

DOI 10.15588/1607-3274-2019-2-13
$I$ is a designation of an information flow associated with the functional dependence $I(t)$, a flow of information from the trainer;

$I_{x}$ is an input information flow;

$I_{y}$. is an output information flow;

$I_{u}$ is an information flow describing the model of the student's representations;

$I()$ is a functional dependence on the argument $t$, which determines the instantaneous value of the information flow amplitude;

${ }^{\circ} I()$ is a random component of an information process, determined by the normalized flow;

$i$ - index variable;

$i$ is an index variable;

$k$ is some specific value of the time variable $t$ in the formula for finding $M\{I\}$ in the cross-section $t=k$;

$\kappa_{i}$ is a quantity of the $i$-th stage segment in the learning path;

$k_{l}{ }_{l}$ is the $l$-th partial learning path $(l=1,2, \ldots, N)$;

$\log _{a}$ is a mathematical operation of calculating the logarithm for the base $a$;

$M$ is a set of elements $m_{i}$;

$M\{\}$ is a function for determining the value of a mathematical expectation used to obtain the expected value of an information flow; 
$M\{\}_{t=k}$ is an expectation for an information flow of the learning process as a random function of a time in the cross-section $t=k$;

$M_{I}()$ is an expectation function associated with the information process $I$ and the time parameter $t$;

$m$ is a number of options;

$m_{i}$ is an $i$-th memory element;

$n$ is a number for topics of the studied course;

$N$ is a variable that stores the number of summable elements;

$P$ is a probabilistic characteristic of an information flow associated with the functional dependence $P(t)$;

$P()$ is a generalized random process that describes an information flow in accordance with a given timeline as a function of the argument $t$;

$P_{i}()$ is an $i$-th discretization of a random process describing an information stream in accordance with a given timeline as a function of the argument $t$;

$r$ is a designation of the barrier function weight;

$S$ is a set of connections $s_{i}$;

$s$ is some connection of memory elements;

sup is a mathematical operation of finding the exact upper bound;

$s_{i}$ is an $i$-th relationship between memory elements;

$t$ is a current time of the information flow passing;

$U^{*}$ is a designation for the optimal control model, described through sequences of the partial trajectories;

$u$ is an information flow while minimizing the student error;

$x$ is an argument of the target function $f($ );

$x^{*}$ is an $x$ value corresponding to the solution of the optimization problem (the optimum point);

$x *_{\Phi}$ is some optimum point $\Phi()$;

$\boldsymbol{x}()$ is some event flow vector;

$\Delta \boldsymbol{a}$ is some deviation of the vector $\boldsymbol{a}$;

$\Delta I$ is an information flow, evaluating the mutual deviation of information flows;

$\Theta$ is a set of weights $\theta_{i}$;

$\theta$ is a weight (significance) of the memory component;

$\theta_{i}$ is some weight characterizing the $i$-th memory component;

$\varphi_{i}()$ is an $i$-th constraint in the optimization problem;

$\Phi()$ is some modified objective function $f()$;

$\Omega$ is a set limiting a possible values of the $x^{*}$.

\section{INTRODUCTION}

The increase in labor market requirements, objectively conditioned by the current realities of the course and the forecasted trends in the development of social and economic processes, requires an increase in the intensification of the specialists (professionals) training.

The learning processes are characterized by high information saturation and dynamism of information spaces for studied subject areas, which determines the high level in relevance and practical value for researching information aspects of learning processes, including such aspects of their study as information, information objects, information processes, information systems and information technologies.

(C) Khodakov V. Ye., Sokolov A. Ye., Veselovskaya G. V., 2019 DOI 10.15588/1607-3274-2019-2-13
Strengthen these features also such factors as increasing activity and the growing volume for information needs and information requests of participants in the learning process.

It is important to consider the information components of the learning processes within a single integrated system, based on the methodology of the system-technical approach.

No less important is also the allocation within this review of a separate, special, more thorough study of such key elements of information systems that provide the learning process, both trainer and trainees.

The object of study is a set of models for trainer and trainees, considered as participants in information interaction.

The subject of study is a set of concepts and ways for modeling the trainer and trainees, studied from the point of view of the basic components for an integrated system of information technologies in teaching.

The purpose of the work is to solve the problems of conceptualization and formalization, aimed at creating methods in modeling the trainer's subsystem in the framework of information technology for training, as well as modeling information flows and information procedures in the model of the trainee's subsystem.

\section{PROBLEM STATEMENT}

The theoretical and applied research conducted in the sphere of modeling systems, processes and technologies for training examined from the point of view of their informational aspects is still not fully complete, detailed and systematically covers issues related to modeling methods for key subsystems of the information system of education, in particular, information subsystems of the trainer, trainee and their dynamic components such as information flows and information procedures [1-16].

Proceeding from the above, the key task of research and development in the presented work was the creation of concepts and modeling methods for the following two basic subsystems of the information learning system: the subsystems of the instructor as a source of dynamic information flows in information technologies of instruction; the subsystem of the trainee, viewed from the point of view of the dynamic information flows and procedures in which he participates as a component of the information learning system.

When modeling the information subsystem of the trainer in the framework of the information technology for education, it was necessary to obtain: for the training information flow $I$ as a time process $I(t)$, having probabilistic elements and considered in time sections $t=$ $k$ - functional dependencies for the expected value $M\{I\}_{t=k}$ and the random component ${ }^{\circ} I()$; structural model of the information subsystem for the trainer, taking into account the consideration of the educational system as an information technology complex with optimization management; the structural model on the dynamics of the information subsystem for the trainer as a generalized object with an inertial link of the first order; formular and 
structural view of the optimization model of learning process control as a movement along information trajectories with minimization of the training error, assessed by scale $\mathrm{C}$.

When modeling the student's information subsystem, from the angle of information flows and information procedures functioning in it, it was necessary to obtain in the work: classification of information flows; structural model of information flows, with the release of the types of information technologies on which it is based; the formula model for transformations of the input information flow $I_{x}$ into the output information flow $I_{y}$ taking into account the peculiarities of the information signal space, memory and memory operator $A$; the formula model for describing information in memory using direct $f$ and inverse $f^{-1}$ transformations of signals carrying information; the formula model of condition for the completion of training as an information process; the structural model of information flows in memory; formula models for estimating the gradient of the deviation for information flows in learning $\operatorname{grad} \Delta I \boldsymbol{a}_{\mathrm{i}}$ taking into account the information reproduction error $\Delta I(a)$, descriptions of the gradient training procedure, the optimization task of learning as an information process using the penalty and barrier function methods; the structural model of the student subsystem as an information system for optimal control of information accumulation

\section{REVIEW OF THE LITERATURE}

Improvement of the modern education is based on the use of advanced technologies related to the categories of computer, network, information, information and communication (including distance) technologies based on advanced hardware and software means of information broadcast, and also possessing a high degree of interactivity [1-12].

Wherein, because of the possibility, the widest range of advantages and achievements in the sphere of modern information systems, processes and technologies is used $[1,4-5,17-23]$.

The basis of the learning processes is the use of information, and, consequently, an important role in ensuring their effectiveness is played by the expedient use of information systems, information processes and, accordingly, information technologies.

In connection with the foregoing, high relevance and practical value have effective models and algorithms for information components of learning processes.

In this regard, the key starting point is the information flows and the corresponding dynamic information procedures in the learning processes, their interactions and models, which was reviewed by the authors in their previous publications.

In this paper, we consider the questions on modeling of the trainer (teacher) subsystem in the information technology of instruction, as well as information flows and information procedures in the model of the student's subsystem.

(C) Khodakov V. Ye., Sokolov A. Ye., Veselovskaya G. V., 2019 DOI 10.15588/1607-3274-2019-2-13
For definiteness of further consideration, we will adopt the most common definition of information technology [6, 17-22, 25-26], according to which, further information will be presented in Table 1 .

It should be noted that information technology is based on the following basic principles: interactive (dialog) mode of operation with a computer; integration with other software products; the flexibility of the process for changing data and setting tasks.

All basic information technologies (Table 1) are used in educational processes, being their basis and the main tool.

The notion of information flow is inextricably linked with the notion of information technology [25-26].

The well-known notion of information flow, which came from logistics [25-26], is evidently inherent in any information system and information technology.

The desire to connect the notion of information flow with the information system and information technology [25-26] leads to the following definition: the information flow is considered the totality of messages circulating within the information system, as well as between this system and the environment external to it, necessary for management and control of information technology operations.

It is advisable to use the classification [25-26] of information flows (Table 2).

Table 1 - Types of information technology

\begin{tabular}{|l|l|}
\hline $\begin{array}{l}\text { Information } \\
\text { technology } \\
\text { classes }\end{array}$ & \multicolumn{1}{|c|}{$\begin{array}{c}\text { Content of activities, related to the } \\
\text { implementation information technologies }\end{array}$} \\
\hline Data processing & $\begin{array}{l}\text { Processing according to a known, specific } \\
\text { algorithm }\end{array}$ \\
\hline Management & $\begin{array}{l}\text { Ensuring the adoption of management } \\
\text { decisions }\end{array}$ \\
\hline $\begin{array}{l}\text { Automated } \\
\text { office }\end{array}$ & $\begin{array}{l}\text { Organization and support of information } \\
\text { processes }\end{array}$ \\
\hline $\begin{array}{l}\text { Support } \\
\text { for } \\
\text { decision- } \\
\text { making }\end{array}$ & $\begin{array}{l}\text { The development of a management decision } \\
\text { that occurs as a result of an iterative process, in } \\
\text { which a decision support system (a } \\
\text { computational link and an object of } \\
\text { management) and a person participate }\end{array}$ \\
\hline $\begin{array}{l}\text { Using } \\
\text { of expert } \\
\text { assessments }\end{array}$ & $\begin{array}{l}\text { Based on the use of artificial intelligence, } \\
\text { expert systems provide an opportunity to } \\
\text { receive expert advice on any problems about } \\
\text { which these systems have accumulated } \\
\text { knowledge }\end{array}$ \\
\hline
\end{tabular}

Table 2 - Classification of information flows

\begin{tabular}{|c|c|}
\hline $\begin{array}{c}\text { Names of } \\
\text { information } \\
\text { flows }\end{array}$ & $\begin{array}{c}\text { Content } \\
\text { of information flows }\end{array}$ \\
\hline Horizontal & $\begin{array}{l}\text { Coverage of messages between partners on } \\
\text { production relations in one level of management }\end{array}$ \\
\hline Vertical & $\begin{array}{l}\text { Coming from above, from the leading instances } \\
\text { to the subordinate instances or links of the } \\
\text { system }\end{array}$ \\
\hline External & Flow in an environment external to the system \\
\hline Internal & Circulate within one system \\
\hline Input & $\begin{array}{l}\text { Messages entering (arriving) to the system or to } \\
\text { one of its subsystems }\end{array}$ \\
\hline Output & $\begin{array}{l}\text { Messages that go beyond one system or one of its } \\
\text { subsystems }\end{array}$ \\
\hline
\end{tabular}


The method of modeling information systems is based on the following "cornerstones": the simplest property of the information flow is one-pointedness (from source to receiver); the narrowness of information interaction only the source and receiver processes; the general principle of modeling is optimality.

On the one hand, the desire to achieve the optimality of the model is considered as a tool for obtaining a valid (which corresponds to the original with the greatest possible deviation or error if possible) representation of the object and its environment, which requires special procedures for finding the appropriate conditions and constraints, and also for the dynamic step-by-step approximation of the model to the object.

On the other hand, the optimality of learning processes models involves the use of optimization procedures in order to obtain an effective representation of information processing processes.

On the third hand, it is the optimization procedures, on which progressive information technologies are based, that make it possible to realize them highly efficiently $[14,16,24]$.

In all the cases presented, we have the following features: the optimality of the modeling for the information components of the training systems is closely associated with the dynamic nature of the information training procedures; the key consequence of the optimization procedures dynamism, which increasingly leads to the need for their consideration as independent dynamic objects and most clearly manifested with a decrease in the step of their sampling, are the significant time costs for optimization, related to the high complexity of the corresponding tasks on system control [14, 16, 24].

An immediate consequence of the above is the need in effective modeling of the dynamics for optimization procedures and the relevance of improving the methods for constructing these models.

It should be noted that there are certain scientific results concerning the speed of convergence for search procedures of the optimal, however, the subject area of methods for modeling optimization procedures that are considered as independent dynamic objects remains extremely inadequate $[14,16,24]$.

It is important to note that the classification that was mentioned above in Table 2 is oriented to various structures that arise in the implementation of information systems, but in any case, there are unidirectional information flows, and for them the approach to structural modeling of information systems is valid.

It should also be noted that the focus on higher efficiency (productivity, effectiveness, reactivity, accuracy, etc.) of information processing processes required improved concepts for determining the amount of information, as well as performing analytical and synthetic operations for research and development of information systems in the information space [13-16, 1922, 24-26].

Let's give a quantitative estimate for the information transmitted from the transmitter to the receiver.

(C) Khodakov V. Ye., Sokolov A. Ye., Veselovskaya G. V., 2019 DOI 10.15588/1607-3274-2019-2-13
The instantaneous value of the information flow amplitude, which coincides with the definition of information [14-16, 24-26], is represented by the formula (1):

$$
I(t)=-\log _{a} P(t) .
$$

The expected value of the information flow is represented by the formula (2):

$$
M\{I\}=-M\left\{\log _{a} P\right\} .
$$

The aim of the research presented below is to solve the problems of conceptualization and formalization, aimed at creating methods for modeling the trainer's subsystem within the information technology of instruction, as well as modeling information flows and information procedures in the model of the trainee's subsystem.

\section{MATERIALS AND METHODS}

The information flow in learning is a random function of time. The mathematical expectation of the specified process in the section $t=k$ is determined by the average (on implementation) value of the information by the formula (3):

$$
M\{I\}_{t=k}=-\sum_{\substack{i=1 \\ t=k}}^{n} P_{i}(t) \log _{a} P_{i}(t)=H_{t=k}(I) .
$$

The entropy of the cross-section of the random process describing the information flow is not random, and determines the expected information for the transmitted information stream. In relation to learning, we have a planned flow of information created by the instructor.

The random component of the information process is determined by the normalized flow by the formula (4):

$$
\stackrel{o}{I}(t)=I(t)-M_{I}(t)=I(t)-H_{I}(t)
$$

Thus, the centered information flow, as a random process, allows you to determine the deviation of information flows, as the trainee's information flow, centered on the entropy of the trainer's flow.

In this case, it is possible to assess the deviation of the learning process from a given trajectory.

Considering the educational system as an information complex, including the trainer's subsystem and the trainee's subsystem, we note that the main properties of this complex are:

- the presence of memory, in which the transmitted information and algorithms for its transmission are stored;

- the availability of an algorithm for comparing the flow of information transmitted to the trainee's subsystem and information reproduced by the trainer; 
- the availability of algorithms for managing the selection of information depending on the deviation of the training stream from the reproduced stream;

- the presence of an objective function or functional and algorithms for optimizing the control of the learning information flow.

In this case, the structural model takes the following form (Fig. 1).

For each block there is information technology. The memory block is supported by the information technology of the automated office, where storage, transformation and transmission of information is envisaged. The memory sampling control unit is based on information technology of expert assessments and decision support.

In its turn, the objective function adopted in the task ensures the application of information control technology.

An essential point is the presence in the structure of the trainer's subsystem the optimization procedure, which ensures the achievement of the necessary level for the criterion of the instruction quality.

The presence of an optimization procedure in the system causes the formation of dynamic properties for the entire subsystem.

Thus, evaluating the optimization procedure as a gradient one, we obtain a model for the dynamics of the trainer`s subsystem as a generalized object with an inertial link of the first order (Fig. 2).

The trainer, having found a deviation in the pupil's presentation about the material presented, with some "dynamic" delay corrects the material presented, reducing the error of the trainee.

Therefore, by dividing the training course into topics and selecting a certain number (let's denote it by $m$ ) of variants for presentation or sequences of information blocks within each of the topics, we can represent the learning process as trajectory motion from initial state to completion of the trajectory, aiming to minimize learning error, estimated scale $C$.

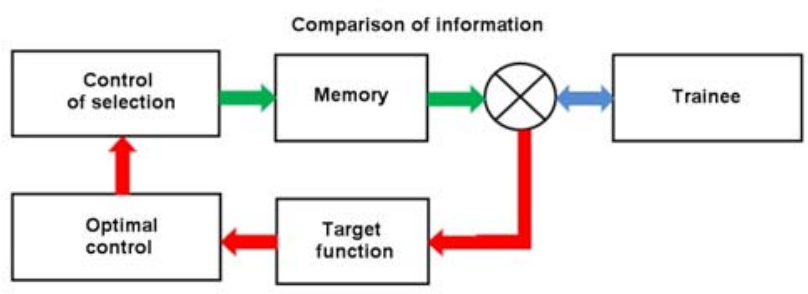

Figure 1 - The structural model for the trainer's subsystem

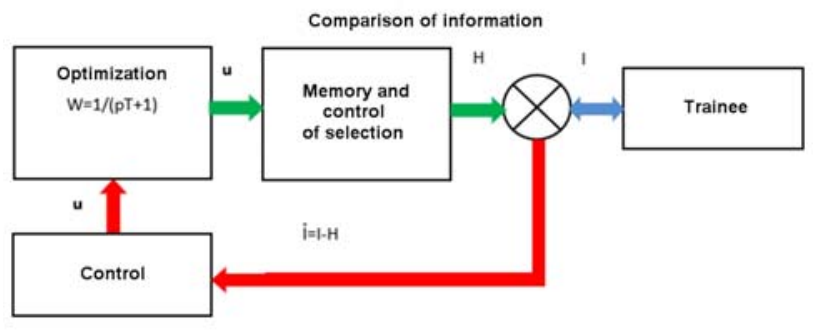

Figure 2 - Model of the trainer's subsystem
In this case, for $N$ topics, where each $i$-th stage contains $\kappa_{\mathrm{i}}$ segments and each segment of the trajectory gives an estimate of $C_{k i}$, we obtain the problem of determining the optimal control as a sequence of partial trajectories, by the formula (5):

$$
U^{*}=\left\{k *{ }_{1}, k{ }_{2}, \ldots, k *{ }_{N}\right\} .
$$

We have the task of dynamic programming, represented by the formula (6):

$$
U^{*} \rightarrow \sup \sum_{i}^{n} C_{i k^{*}}
$$

In this way, the learning path is selected (Fig. 3).

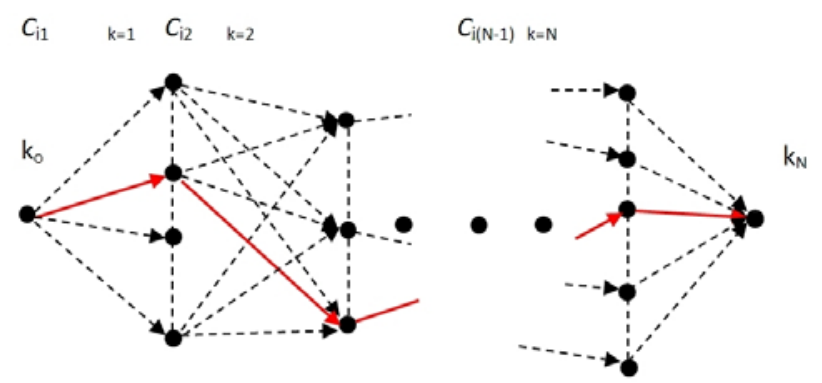

Figure 3 - Choosing the optimal trajectory of learning

The solution of this problem is determined by the Bellman principle, within the framework of the dynamic programming method $([13-16,24]$ - the optimum is achieved by a search of variants with backward and forward movement).

Important is the process of changing the state of the teacher in time. The environment changes - the knowledge amount of the learner changes, the traveled trajectory of learning is accumulated. Consequently, the trainer`s subsystem is not stationary.

Compensation for degrading trends is achieved through additional training, attestation and retraining.

Consider information procedures in the model of the trainee's subsystem.

The evaluation of learning is approved for the results: the repetition of the information received from the instructor; the construction of a model adequate to the description given by the instructor. The following information flows are distinguished in the trainee's subsystem (Figure 4):

$-I$ - information flow of the trainer;

$-I_{u}$ - a flow of information describing the model constructed by the trainee, based on information stored in the trainee's memory;

$-\Delta I-$ the information flow estimating the deviation of the instructor's information and the student's presentation;

$-u$ - the information flow created when the trainee's error is minimized. 
The model shown in Fig. 4, relies on the information technology for decision making by the trainer and data processing when correcting the content of memory, as well as the technology for information systems control while minimizing the presentation error:

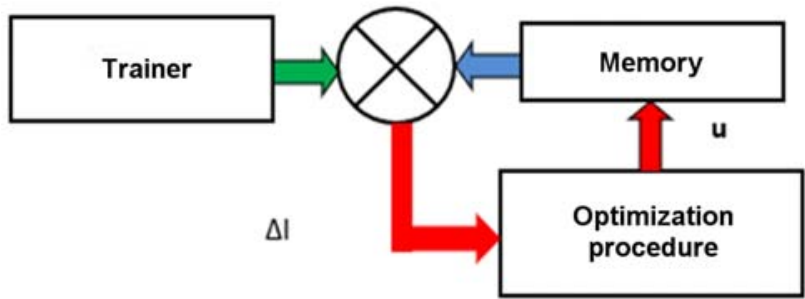

Figure 4 - Information flows in the trainee's subsystem

This view is based on the process for identifying the model of the surrounding world through training, as a correction for the contents of memory.

The gradualness of information perception observed during training is related to the dynamic properties of the algorithm for minimizing learning errors, which are individual and must be taken into account when forming the information flow of the instructor.

Despite the convenience of describing the model using the notion of information flows, it is not possible to completely ignore the signal space. Describing the memory as a set of elements $\left\{m_{i}\right\}$, the set of connections $\left\{s_{i}\right\}$, and the set of weights $\left\{\theta_{i}\right\}$, we can represent the memory model as a triplet of sets $M, S, \Theta$.

The specified triple forms the memory operator $A$, as its subset, which ensures the transformation of the input information stream $I_{x}$ into the output information stream $I_{y}$. In this case, the memory operator depends on the parameter vector a, with the components $m, s, \theta$, and we can write, by the formula (7):

$$
A(\mathbf{a}) * I_{x}=I_{y} .
$$

In this case, it is necessary to take into account that the incoming information flow $I_{x}$ does not interact with the entire set $M$, but only with its subset having dimension $\operatorname{dim} X$.

The necessary condition for the absence of information loss during the conversion by memory is the condition of preserving the dimension $\operatorname{dim} X=\operatorname{dim} Y$.

Considering that the information flow is inextricably linked with the flow of events $\boldsymbol{x}(t)$, at the same time, that the external information flow and the information flow in memory do not need to have the same signal space, select the signal conversion operator $f$.

In this case, the transformation operator does not influence the information flow, that is, $f(I)=I$, but it converts the signals carrying the information.

In this case, the information inside the memory is described as follows, by the formula (8):

$$
f(I)=I \quad \rightarrow \quad A(\mathbf{a}) * f\left(I_{x}\right)=I_{y}
$$

The adopted learning paradigm requires the learner to reproduce the information received from the instructor. Therefore, it is also need to execute the reverse transformation, by the formula (9):

$$
A^{-1}(\mathbf{a}) * f^{-1}\left(I_{y}\right)=I_{x} .
$$

However, the mapping (9) does not necessarily exist, since the operator $A$ defines a one-to-one mapping only if the information $I_{x}$ (or a part of it) is already mapped in the memory.

The condition for completing the training we obtain in a simple form, by the formula (10):

$$
A^{-1}(\mathbf{a}) * f^{-1}\left(A(\mathbf{a}) * f\left(I_{x}\right)\right)=I_{x} .
$$

Assuming the linearity of the operators $f(I)$ and $f^{-1}(I)$, we can write by the formula (11):

$$
f^{-1}\left(A(\mathbf{a}) * f\left(I_{x}\right)\right)=A(\mathbf{a}) * f^{-1} * f\left(I_{x}\right) .
$$

Therefore, taking into account (11), we obtain the condition for completing the training in the form of the formula (12):

$$
\left.f * f^{-1}=1 \quad \rightarrow \quad \begin{array}{c}
A^{-1}(\mathbf{a}) * A(\mathbf{a})=1 \\
\operatorname{dim} X=\operatorname{dim} Y
\end{array}\right\}
$$

Condition (12) says that information is assimilated if convolution of associative and direct memory results in an identity operator.

Condition (12) is only a formalization of the accepted learning paradigm, but it allows to obtain a structural model of information flows in memory, while learning (Fig. 5).

The nondegeneracy condition of the transformation, taking into account the conservation of dimension, generates a learning procedure based on the sequential determination of the vectors $\boldsymbol{a}$, which ensure the selection of a nondegenerate transformation with a sequential increase in dimension, up to a dimension that ensures the identity of the input information stream and the information flow generated by the model.

Thus, the training procedure consists of a sequence of steps to minimize the information reproduction error $\Delta I(\boldsymbol{a})$, with a consecutive increase in the dimension of the memory operator, condition (12).

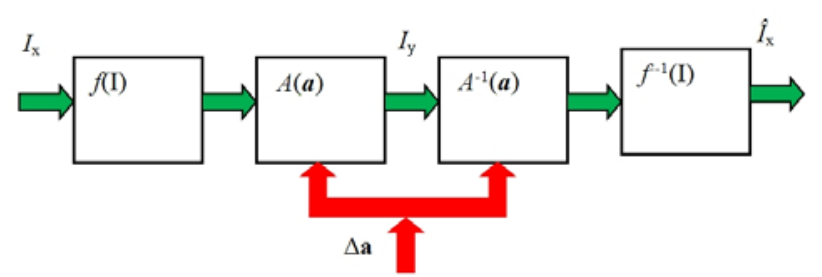

Figure 5 - Information flows in memory during training 
Restricting ourselves to the gradient optimization procedure [13-16, 24], we obtain to estimate the gradient of the information flow deflections by the formula (13):

$$
\operatorname{grad} \Delta I_{\mathbf{a}_{i}} \approx \frac{\Delta I\left(\mathbf{a}_{i}+\Delta \mathbf{a}\right)-\Delta I\left(\mathbf{a}_{i}\right)}{\Delta \mathbf{a}} .
$$

Using gradient estimation (13), we will write the learning procedure as a gradient procedure by the formula (14):

$$
\mathbf{a}_{i+1}=\mathbf{a}_{i}+\frac{\operatorname{grad} \Delta I_{\mathbf{a}_{i}}}{\left|\operatorname{grad} \Delta I_{\mathbf{a}_{i}}\right|} .
$$

Since for a gradient procedure the starting point of motion is essential, we define the initial non-degenerate operator $A_{0}$, formed by a subset included in the set that generates the required operator. This is the mapping of the principle from simple to complex.

As a consequence, we come to the methods of penalty and barrier functions, with the inherent dangers in the appearance of gully.

In fact, the method of barrier functions, in this case, is used to solve a problem with restrictions of the inequalities type for the dimension of the memory operator.

So, assuming the existence of an objective function $f(\boldsymbol{x})$ and the limitations $\varphi_{\mathrm{i}}(\boldsymbol{x})<0, \mathrm{i}=1,2, \ldots, n$, an optimization problem is posed, represented by the formula (15):

$$
\begin{gathered}
x^{*} \rightarrow \min f(x), \\
x^{*} \in \Omega \mid \varphi_{i}(x)<0, i=1,2, \ldots, m .
\end{gathered}
$$

Within the framework of the method, a change in the goal function is provided such that when approaching the boundary, there is a "repulsion" from the barrier formed by constraints (Fig. 6).

To organize a "barrier", the restriction $\varphi_{i}<0 ; i=1$, $2, \ldots, m$ is usually used, taking into account that the actual boundary is given by equations $\varphi_{i}=0 ; i=1,2, \ldots, m$.

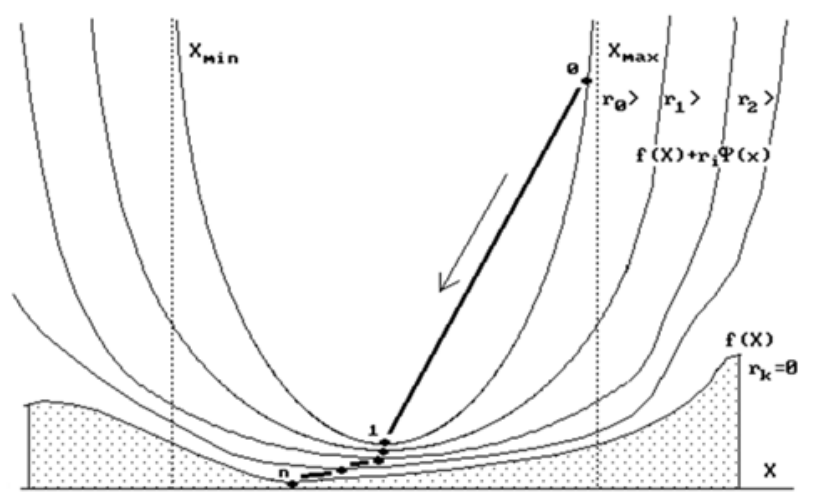

Figure 6 - Method of barrier functions
Thus, we form a new goal function by the formula $(16)$

$$
\Phi(x)=f(x)+\sum_{i=1}^{m} \frac{1}{\varphi_{i}^{2}(x)} .
$$

and, using the gradient procedure, we solve the problem in finding the minimum of a new objective function $\Phi(x)$, we find the point of its minimum $\boldsymbol{x}_{\Phi}{ }^{*}$, which, in general, does not coincide with the optimum point $x^{*}$ because of the barrier function influence.

To eliminate the error in the $x^{*}$ definition, we eliminate the influence of the barrier function by organizing a stepping procedure with decreasing barrier function weight, by the formula (17):

$$
\begin{gathered}
r_{1}>r_{2}>\ldots>r_{k}=0, \\
\Phi_{j}(x)=f(x)+r_{j} \sum_{i=1}^{m} \frac{1}{\varphi_{i}^{2}(x)}, j=1, \ldots, k .
\end{gathered}
$$

The number of steps for the procedure $k$ and the sequence $r_{j}$ are chosen in advance from the conditions of the problem.

Thus, a sequence of connecting the elements to the model formed in the memory is formed.

In a situation where there is no single-valued memory operator, its search can be provided using the method of penalty functions.

When solving a problem with constraints of equations type, represented by the formula (18):

$$
\begin{gathered}
x^{*} \rightarrow \min f(x), \\
x^{*} \in \Omega \mid \varphi_{i}(x)=0, i=1,2, \ldots, m,
\end{gathered}
$$

a similar method is used.

The difference is in the formation of the penalty function, which is assigned in such a way as to ensure the approach to the border, by the formula (19):

$$
\begin{gathered}
r_{1}<r_{2}<\ldots<r_{k}>0, \\
\Phi_{j}(x)=f(x)+r_{j} \varphi_{i}^{2}(x), j=1, \ldots, k .
\end{gathered}
$$

The disadvantage of this method is its "ravine type", which requires the use of the steepest descent method at each of the steps.

Thus, it is possible to construct a structural model of the trainee's subsystem as an information system for optimal control of information accumulation (Fig. 7).

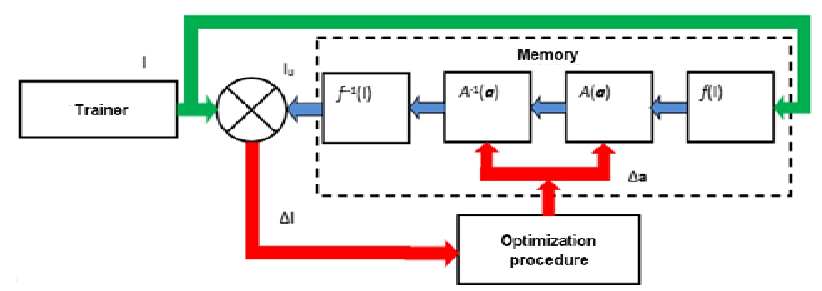

Figure 7 - Model of the trainee's subsystem 
We got a conception for the process of information accumulation by an information and control system with a goal functional, defined as the minimum deviation in the information flow of the trainer from the information stream being reproduced by the trainee. This model allows us to evaluate the dynamics of the process.

Based on the evaluation for the dynamics of the gradient procedure, which determines the behavior of the entire subsystem, one can construct a simple model similar to the gradient procedure model.

Assuming that the information flow of the trainer increases its intensity step by step, according to the degree in assimilation of the material, we get a simple model (Fig. 8, 9).

For clarity, we use the tools of the SIMULINK system, which allow us to obtain convenient models of system dynamics.

In Fig. 8 the information flow from the trainer $I$ is modeled by a series of pulse parcels storing the input information Ic.

The accumulation of information by trainee $I u$ is determined taking into account the dynamics of the optimization procedure.

The transient processes in Fig. 9 illustrate the possibility of coordinating the information flow of the learner with the trainee's capabilities.

At optimum coordination, the moment of end for fragment preservation is combined with the beginning for the following fragment of a training trajectory.

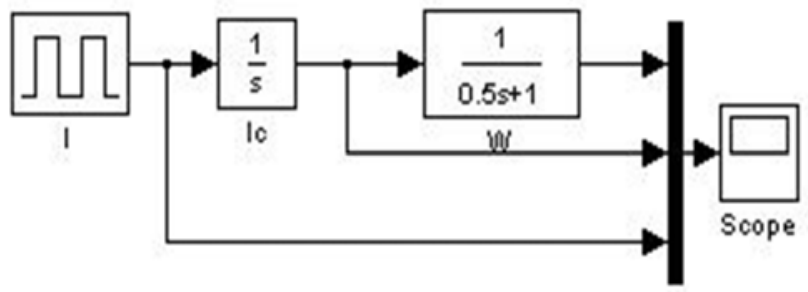

Figure 8 - Modeling the dynamics of information accumulation (scheme of the model executed in the SIMULINK system)

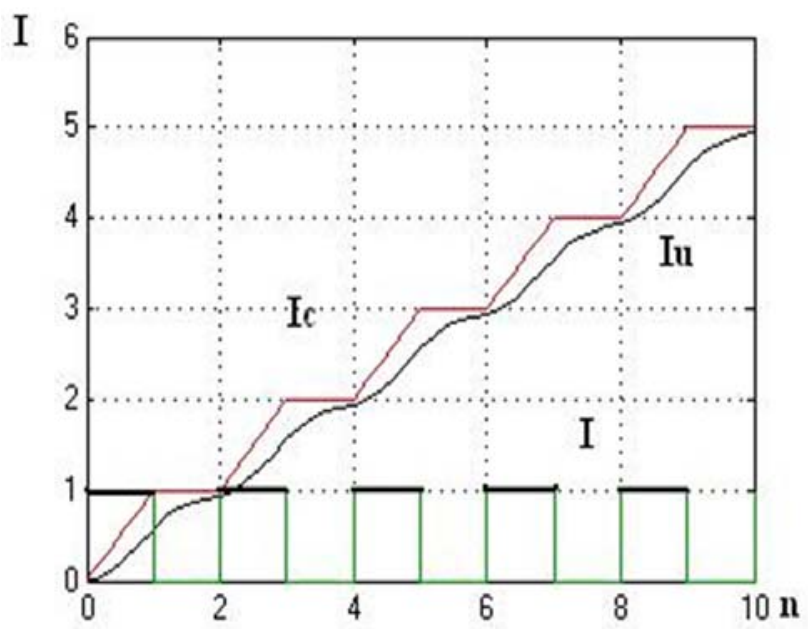

Figure 9 - Modeling the dynamics of the information accumulation (in SIMULINK system)

(C) Khodakov V. Ye., Sokolov A. Ye., Veselovskaya G. V., 2019 DOI 10.15588/1607-3274-2019-2-13

\section{EXPERIMENTS}

The implementation of the experiment was based on a set of programs (both standard and expanding the range of their functional capabilities of author's developments), which allowed to realize the generalized models of trainer and trainees as key subsystems of information learning systems, as well as to make their expert evaluation.

The trainer and trainees models were tested in such a way that the initial data for testing models were combined into 150 tuples of data.

Based on the experimental results, the validity estimates of the trainer and trainees models were obtained, from which it follows that the obtained and the reference values of these estimates coincide.

\section{RESULTS}

The following results were obtained.

1. The analysis on the development in the theory and practice of learning is carried out, the special relevance and practical value of the information approach to the modeling of learning systems is highlighted.

2. As the key objects of the study, the models for the information subsystems of trainer and trainees are considered.

3. The modeling for the trainer subsystem in the framework of the training information technology is performed.

4. The generalized methods for modeling the trainer and trainees subsystems are obtained.

The models of trainer and trainees were implemented programmatically, studied in real learning processes, and the results of these studies (in the form of generalization of demonstrative samples of experimental data, with a sample length of 150) are summarized in Table 3 and Table 4

Table 3 shows four types of trainers, in accordance with their relative graduation in terms of professional qualifications: Type I - Doctors of Sciences, Professors; type II - Candidates of Sciences (Ph.D.), Associate Professors; type III - Seniors Lecturers; type IV Assistants and Trainee Teachers.

The resulting data in Table 3 shows the following positive increments of the indicators: increment 1 according to the speed of training; increment 2 - by coverage of training information; increment 3 -according to the quality of knowledge achieved by the trainees; increment 4 - integral increment (generalized for all indicators).

The demonstrative characteristics (Table 3) of the learning processes effectiveness are improved due to the introduction of the generated methods for modeling the information subsystem of the educator, including for those with a lower category of professional qualification. 
Table 3 - The model of the trainer information subsystem

\begin{tabular}{|c|c|c|c|c|c|c|}
\hline \multirow{2}{*}{$\begin{array}{c}\text { Type } \\
\text { of trainers }\end{array}$} & \multirow{2}{*}{ 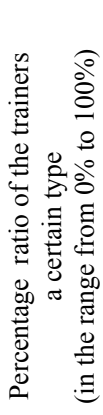 } & \multirow{2}{*}{ 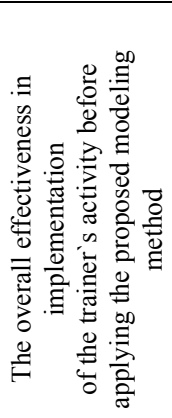 } & \multicolumn{4}{|c|}{$\begin{array}{l}\text { Positive dynamics } \\
\text { in the effectiveness } \\
\text { of training activities } \\
\text { based on the practical } \\
\text { implementation results } \\
\text { of the developed } \\
\text { modeling methods: }\end{array}$} \\
\hline & & & 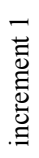 & $\begin{array}{l}\sim \\
\stackrel{0}{0} \\
\text { Ẽ } \\
\stackrel{0}{0} \\
. \Xi\end{array}$ & 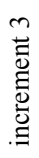 & 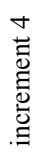 \\
\hline Type I & 10 & 90 & 6 & 10 & 8 & 8 \\
\hline Type II & 30 & 80 & 4 & 6 & 5 & 5 \\
\hline Type III & 30 & 70 & 3 & 5 & 4 & 4 \\
\hline Type IV & 30 & 60 & 3 & 3 & 3 & 3 \\
\hline $\begin{array}{l}\text { Average } \\
\text { value }\end{array}$ & 25 & 75 & 4 & 6 & 5 & 5 \\
\hline
\end{tabular}

Table 4 shows six types of trainees that correlate in academic performance with the European grading scale for the EKTS grades as follows: type $1-\mathrm{A}$; type $2-\mathrm{B}$; type $3-\mathrm{C}$; type $4-\mathrm{D}$; type $5-\mathrm{E}$; type $6-\mathrm{F}$, FX. The results shown in Table 4 are the following increments: 1 to reduce the duration for the implementation of information activities by the trainees in the learning process; 2 - to increase the amount of information consumed by trainees; 3 - in increasing quality assimilation of information by trainees; $4-$ on the integrated indicator for the effectiveness of learning activities within the information subsystem of the trainee.

The results of the trainees activity improved for all types of research, and, especially, for the most problematic type, six where previously positive estimates were mainly obtained exclusively after a number of retakes.

The conducted experiment confirmed the effectiveness of the generalized methods for modeling information subsystems of trainer and trainees, taking into account, as an actual factor, the dynamics of information procedures in the training system.

Table 4 - The model of the trainee information subsystem

\begin{tabular}{|c|c|c|c|c|c|c|}
\hline \multirow{2}{*}{$\begin{array}{l}\text { Type } \\
\text { of } \\
\text { trainees }\end{array}$} & \multirow{2}{*}{ 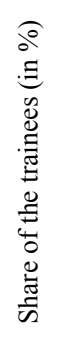 } & \multirow{2}{*}{ 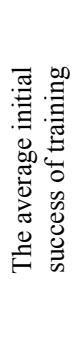 } & \multicolumn{4}{|c|}{$\begin{array}{c}\text { Positive dynamics } \\
\text { of learning outcomes } \\
\text { when using } \\
\text { the proposed modeling methods }\end{array}$} \\
\hline & & & 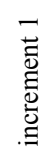 & 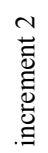 & 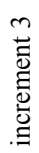 & 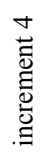 \\
\hline Type 1 & 10 & 92 & 2 & 3 & 1 & 2 \\
\hline Type 2 & 20 & 86 & 3 & 5 & 4 & 4 \\
\hline Type 3 & 20 & 78 & 7 & 6 & 5 & 6 \\
\hline Type 4 & 20 & 69 & 9 & 9 & 6 & 8 \\
\hline Type 5 & 20 & 62 & 12 & 11 & 10 & 11 \\
\hline Type 6 & 10 & 40 & 15 & 14 & 22 & 17 \\
\hline $\begin{array}{l}\text { Averag } \\
\text { e value }\end{array}$ & 16,6 & 83.5 & 8 & 8 & 8 & 8 \\
\hline
\end{tabular}

(C) Khodakov V. Ye., Sokolov A. Ye., Veselovskaya G. V., 2019 DOI 10.15588/1607-3274-2019-2-13

\section{DISCUSSION}

The modeling methods expand and supplement the tools of modeling. As a result, it is important to note the following:

- the currently existing theoretical and practical research and development on a number of authors' collectives and individual authors mainly reflect separately taken, isolated subproblems in the methodology of modeling for dynamic information systems (objects, processes, procedures, technologies, etc.) related to teaching by trainers and assimilation by trainees, which does not allow, on the whole, to obtain a sufficiently satisfactory state of the general model;

- the methods in modeling for the information subsystems of the trainer and trainees developed by the authors of this publication expand the capabilities of previously developed by other authors methodological developments, allowing to significantly increase the effectiveness of information learning processes (according to Tables 3 and Table 4, the integral indicators of effectiveness increase by $5 \%$ and $8 \%$ respectively).

\section{CONCLUSIONS}

In paper, the results of research on the methods formation in modeling of information subsystems for the trainer and trainees, complementing and developing existing approaches were presented.

The carried out experiment substantiated the practical effectiveness of the proposed modeling methods and the expediency of using them to enhance the effectiveness of information subsystems of the trainer and trainees.

The scientific novelty of the achieved results consists in the fact that for the first time methods have been proposed for modeling the trainer subsystem within the learning information technology, as well as information flows and information procedures in the trainee's subsystem, which are based on the complex application of the information theory methodological apparatus and the conceptual basis of studying the activity processes for the trainer and trainees as integral, purposeful, dynamically proceeding information processes, which are a full-scale complex of interrelated information procedures to provide the required state for information base of trainees competencies.

The proposed methods make it possible to ensure, with an allowable accuracy, the optimal modeling for information subsystems of the trainer and trainees taking into account the dynamics factor, which makes it possible: to reduce the time intervals for the flow of information learning processes; to increase the volumes of information presented, consumed and qualitatively assimilated at the theoretical and practical level. Accordingly, a higher level of knowledge, abilities and skills of the trainees is achieved, with reception them the best points.

Within the created methods, key concepts and mathematical modeling apparatus of information subsystems for trainer and trainees are proposed. 
The practical significance of the work results is to ensure that they increase the effectiveness of information subsystems for the trainer and trainees.

Prospects for further development of the work involve the consideration in a more wide range of the characterization aspects for the information subsystems of the trainer and trainee, as well as the results of their activities.

\section{ACKNOWLEDGEMENTS}

This work, which is a logical continuation of the research, the results of which were published in [27], was carried out at the Information Technology Department of the Cybernetics and Systems Engineering Faculty in Kherson National Technical University, within the framework of a single set on research tasks for the international program "Erasmus + KA2 - Cooperation for innovation and the exchange of good practices - Capacity Building in the field of Higher Education", an international project 561728-EPP-1-2015-1-ES-EPPKA2CBHE-JP "GameHub: University-enterprises cooperation in game industry in Ukraine", and the research project "Development of software for analysis of the organizational structure of the enterprise" with state registration PK0116U005663.

\section{REFERENCES}

1. Willcox K. E., Sarma S., Lippel P. H. Online education : a catalyst for higher education reforms. Massachusetts Institute of Technology online education policy initiative (Final Report). Cambridge: MIT, 2016, 56 p.

2. Zorn A., Haywood, J. Glachant J., Eds Higher education in the digital age. Moving academia online. Cheltenham, UK, Northampton, MA, USA, Edward Edgar Elgar Publishing, 2018, $170 \mathrm{p}$.

3. Xing W., Fei G. Exploring the relationship between online discourse and commitment in Twitter professional learning communities, Computers \& Education, 2018, No. 126, pp. 388-398.

4. Joshi A., Meza J., Costa S., Puricelli Perin D. M., Trout K., Rayamajih A. The role of information and communication technology in community outreach, academic and research collaboration, and education and support services (ITCARES), Perspective in helth information management (online research journal), 2013, Volume 10 (Fall), 15 p.

5. Saidani N. Towards a better comprehension of adaptation to information and communication technologies : a multi-level approach, Dissertation of $\mathrm{PhD}$. Georgia State University, USA, 2016. - $220 \mathrm{p}$

6. Buinytska O. P. Informatsiini tekhnolohii ta tekhnichni zasoby navchannia. Kiev, Tsentr navchalnoi literatury, 2017 , $240 \mathrm{p}$.

7. Kureychik V. V., Bova V. V., Nuzhnov E. V., Rodzin S. I Integrirovannaya instrumentalnaya sreda podderzhki innovatsionnykh obrazovatelnykh protsessov, Otkrytoye obrazovaniye, 2010, No. 4, pp. 101-111.

8. Rastrigin L. A., Erenshteyn M. Kh. Adaptivnoye obucheniye s modelyu obuchayemogo. Riga, Zinatne, 1988, 160 p.

9. Mazurok T. L. Sinergeticheskaya model individualizirovannogo upravleniya obucheniyem, Matematicheskiye mashiny i sistemy, 2010, No. 3, pp. 124134

10. Kureychik V. V., Bova V. V. Modelirovaniye protsessa predstavleniya znaniy $\mathrm{v}$ intellektualnykh obuchayushchikh sistemakh na osnove kompetentnostnogo podkhoda, Otkrytoye obrazovaniye, 2014, No. 3, pp. 42-48.

11. Trembach V. M. Sistemy upravleniya bazami evolyutsioniruyushchikh znaniy dlya resheniya zadach nepreryvnogo obrazovaniya. Moscow, MESI, 2013, 255 p.

12. Lisitsyna L. S. Metodologiya proyektirovaniya modulnykh kompetentnostno-oriyentirovannykh obrazovatelnykh programm: metodicheskoye posobiye. SPb, SPbGU ITMO, $2009,50 \mathrm{p}$.

13. Solomon J. Numerical algorithms: methods for computer vision, machine learning, and graphics : textbook. USA, CRC Press (AK Peters, Ltd.), 2015, 400 p.

14. Yang $\mathrm{X}$. Optimization techniques and applications with examples. USA, UK, WILEY, 2018, $384 \mathrm{p}$

15. Stecca G. Eds.: Operations research applications. Italy, AIRO (Associazone Italiana di Ricerca Operativa), 2017, 123 p.

16. Chernorutskiy I. G. Metody optimizatsii v teorii upravleniya: uchebnoye posobiye. SPB, Piter. 2004, 256 p.

17. Information technology strategy 2018-21: annual report of progress planned GB.331-PFA-5-2018, Eds. : Information and technology management department, Inernetional labour office. Geneva, Switzerland, INFOTEC, ILO, 2017, 26 p.

18. Measuring the information society report 2018, Eds.: International Telecommunication Union, Sanou B. Geneva, Switzerland, ITU Publications, 2018, Volume 1, 204 p.

19. Rocha A., Adeli H., Reis L. P., Costanzo S. Eds. Trends and advances in information systems and technologies, 2018 World conference on information systems and technologies WorldCIST'18, Naples, Italy, 27-29 March, 2018 : proceedings. Naples, Italy, Springers International Publishing, 2018, Volume 3 (347), 406 p.

20. Hammoudi S., Smialek M., Camp O., Filipe J., Eds. Enterprise information systems, 20-th International conference ICEIS 2018, Funchal, Madeira, Portugal, 21-24 March, 2018, proceedings. Madeira, Portugal, SciTePress, Science Technology Publications, Lda, 2018, Volume 1, $440 \mathrm{p}$.

21. Nagamalai D., Meghanathan N. Eds. Computer Science and Information Technology, Forth International conference CoSIT-2017, Geneva, Switzerland, 25-26 March, 2017, proceedings. Geneva, Switzerland, AIRCC Publishing Corporation, 2017, $208 \mathrm{p}$.

22. Antonenko V. M., Mamchenko S. D., Rohushyna Yu. V. Suchasni informatsiini systemy i tekhnolohii: upravlinnia znanniamy, navchalnyi posibnyk. Irpin, Natsionalnyi universytet DPS Ukrainy, 2016, 212 p.

23. Tabunshchyk H. V., Kudermetov R. K., Prytula A. V. Proektuvannia, modeliuvannia ta analiz informatsiinykh system, navchalnyi posibnyk. Zaporizhzhia, ZNTU, 2011, $292 \mathrm{p}$.

24. Esipov B. A. Metody optimizatsii i issledovaniya operatsiy. Konspekt lektsiy, uchebnoye posobiye. Samara, Izd-vo Samar. aerokosm. un-ta. 2007, 180 p.

25. Informatsiini potoky ta yikh klasyfikatsiia. Elektronnyi resurs. Rezhym dostupu : http: // pidruchniki.com / 68003 / logistika / informatsiyni potoki klasifikatsiya].

26. Devyanin P. N. Modeli bezopasnosti informatsionnykh potokov. Modeli bezopasnosti informatsionnykh sistem: uchebnoye posobiye dlya studentov vysshikh uchebnykh zavedeniy. Moscow, "Akademiya", 2005, 468 p., P. 55-66.

27. Khodakov V. Ye., Sokolov A. Ye., Veselovskaya G. V. Models of training procedures, Radio Electronics, Computer Science, Control, 2018, No. 4 (47), pp. 51-60. DOI: 10.15588/1607-3274-2018-4-5.

Received 02.10.2018. Accepted 11.02.2019. 


\section{МОДЕЛЮВАННЯ ТОГО, ЯКИЙ НАВЧАС, ТА ТИХ, ЯКИХ НАВЧАЮТЬ, НА ЗАСАДАХ КОМПЛЕКСНОГО ІНФОРМАЦЙНОГО ПІДХОДУ ДО ВДОСКОНАЛЮВАННЯ ІНФОРМАЦІЙНИХ ТЕХНОЛОГІЙ І СИСТЕМ НАВЧАННЯ}

Ходаков В. Є. - д-р техн. наук, професор, завідувач кафедри інформаційних технологій Херсонського національного технічного університету, Херсон, Україна.

Соколов А. С. - канд. техн. наук, доцент, доцент кафедри інформаційних технологій Херсонського національного технічного університету, Херсон, Україна.

Веселовська Г. В. - канд. техн. наук, доцент, доцент кафедри інформаційних технологій Херсонського національного технічного університету, Херсон, Україна.

Актуальність. Розглянуто задачу обгрунтування методів побудови моделей того, який навчає, та тих, яких навчають, що враховують особливості їхньої інформаційної діяльності. Об'єктом дослідження були моделі того, який навчає, та тих, яких навчають, як учасників інформаційної взаємодії. Мета роботи - розв'язування задач концептуалізації та формалізації, орієнтованих на моделювання підсистеми того, який навчає, в рамках інформаційної технології навчання, а також на моделювання інформаційних потоків та інформаційних процедур в моделі підсистеми того, якого навчають.

Метод. Ключовими складовими систем і процесів навчання $є$ той, який навчає, та ті, яких навчають. Виділені істотні особливості інформаційної взаємодії того, який навчає, та тих, яких навчають. В основу покладене поняття інформаційного потоку, виділені специфічні властивості інформаційних потоків, характерні для процесів навчання та важливі для їхнього успішного перебігу. Запропоновано методи моделювання ключових компонентів системи навчання як інформаційної системи, таких як: підсистема того, який навчає, розглянута з точки зору застосування інформаційних технологій навчання; підсистема того, якого навчають, що надається під кутом зору задіяння інформаційних потоків та інформаційних процедур.

Результати. Запропоновані моделі реалізовані програмно та вивчені практично в процесах навчання в підсумку відпрацювання завдань моделювання того, який навчає, та тих, яких навчають, як учасників інформаційної взаємодії.

Висновки. Проведений експеримент підтвердив дієвість і валідність концепцій і формалізмів, доцільність їхнього впровадження в інформаційні системи, процеси та технології навчання з метою підвищення ефективності процесів отримання та практичного втілення моделей інформаційної діяльності того, який навчає, та тих, яких навчають. Подальший розвиток досліджень передбачає розгляд ширшого кола аспектів інформаційної діяльності того, який навчає, та тих, яких навчають, а також відповідних експериментальних апробацій.

КЛЮЧОВІ СЛОВА: моделювання, той, який навчає, той, якого навчають, інформація, інформаційні системи, інформаційні процеси, інформаційні технології.

УДК 510.6

\section{МОДЕЛИРОВАНИЕ ОБУЧАЮЩЕГО И ОБУЧАЕМЫХ НА ОСНОВЕ КОМПЛЕКСНОГО ИНФОРМАЦИОННОГО ПОДХОДА К СОВЕРШЕНСТВОВАНИЮ ИНФОРМАЦИОННЫХ ТЕХНОЛОГИЙ И СИСТЕМ ОБУЧЕНИЯ}

Ходаков В. Е. - д-р техн. наук, профессор, заведующий кафедрой информационных технологий Херсонского национального технического университета, Херсон, Украина.

Соколов А. Е. - канд. техн. наук, доцент, доцент кафедры информационных технологий Херсонского национального технического университета, Херсон, Украина.

Веселовская Г. В. - канд. техн. наук, доцент, доцент кафедры информационных технологий Херсонского национального технического университета, Херсон, Украина.

\section{АННОТАЦИЯ}

Актуальность. Рассмотрена задача обоснования методов построения моделей обучающего и обучаемых, учитывающих особенности их информационной деятельности. Объектом исследования являлись модели обучающего и обучаемых как участников информационного взаимодействия. Цель работы - решение задач концептуализации и формализации, ориентированных на моделирование подсистемы обучающего в рамках информационной технологии обучения, а также на моделирование информационных потоков и информационных процедур в модели подсистемы обучаемого.

Метод. Ключевыми составляющими систем и процессов обучения являются обучающий и обучаемые. Выделены существенные особенности информационного взаимодействия обучающего и обучаемых. В основу положено понятие информационного потока, выделены специфические свойства информационных потоков, характерные для процессов обучения и важные для их успешного протекания. Предложены методы моделирования ключевых компонентов системы обучения как информационной системы, таких как: подсистема обучающего, рассматриваемая с точки зрения применения информационных технологий обучения; подсистема обучаемого, представляемая под углом зрения задействования информационных потоков и информационных процедур.

Результаты. Предложенные модели реализованы программно и изучены практически в процессах обучения в итоге отработки заданий моделирования обучающего и обучаемых как участников информационного взаимодействия.

Выводы. Проведенный эксперимент подтвердил действенность и валидность концепций и формализмов, целесообразность их внедрения в информационные системы, процессы и технологии обучения с целью роста эффективности процессов получения и практического воплощения моделей информационной деятельности обучающего и 
обучаемых. Дальнейшее развитие исследований предполагает рассмотрение более широкого круга аспектов информационной деятельности обучающего и обучаемых, а также соответствующих экспериментальных апробаций.

КЛЮЧЕВЫЕ СЛОВА: моделирование, обучающий, обучаемый, информация, информационные системы, информационные процессы, информационные технологии.

\section{ЛІТЕРАТУРА / ЛИТЕРАТУРА}

1. Willcox K. E. Online education : a catalyst for higher education reforms / K. E. Willcox, S. Sarma, P. H. Lippel // Massachusetts Institute of Technology online education policy initiative (Final Report). - Cambridge : MIT, 2016. $56 \mathrm{p}$.

2. Higher education in the digital age. Moving academia online / Eds.: A. Zorn, J. Haywood, J. Glachant. - Cheltenham, UK, Northampton, MA, USA : Edward Edgar Elgar Publishing, 2018. $-170 \mathrm{p}$.

3. Xing W. Exploring the relationship between online discourse and commitment in Twitter professional learning communities / W. Xing, G. Fei // Computers \& Education. 2018. - № 126. - P. 388-398.

4. Joshi A. The role of information and communication technology in community outreach, academic and research collaboration, and education and support services (ITCARES) / [A. Joshi, J. Meza, S. Costa et al. ] // Perspective in helth information management (online research journal). - 2013. - Volume 10 (Fall). - 15 p.

5. Saidani N. Towards a better comprehension of adaptation to information and communication technologies : a multi-level approach / Dissertation of PhD. - Georgia State University, USA, 2016. - $220 \mathrm{p}$.

6. Буйницька О. П. Інформаційні технології та технічні засоби навчання / О.П.Буйницька. - К. : Центр навчальної літератури, 2017. - 240 с.

7. Интегрированная инструментальная среда поддержки инновационных образовательных процессов [В. В. Курейчик, В. В. Бова, Е. В. Нужнов, С. И. Родзин] // Открытое образование. - 2010. - № 4. - С. 101-111.

8. Растригин Л. А. Адаптивное обучение с моделью обучаемого / Л. А. Растригин, М. Х. Эренштейн. - Рига : Зинатне, 1988. - $160 \mathrm{c}$.

9. Мазурок Т. Л. Синергетическая модель индивидуализированного управления обучением // Математические машины и системы / Т. Л. Мазурок. 2010. - № 3. - С. 124-134.

10. Курейчик В. В. Моделирование процесса представления знаний в интеллектуальных обучающих системах на основе компетентностного подхода / В.В.Курейчик, В. В. Бова // Открытое образование. - 2014. - № 3. C. $42-48$.

11. Трембач B. М. Системы управления базами эволюционирующих знаний для решения задач непрерывного образования / В. М. Трембач. - М. : МЭСИ, 2013. $-255 \mathrm{c}$.

12. Лисицына Л. С. Методология проектирования модульных компетентностно-ориентированных образовательных программ : методическое пособие / Л. С. Лисицына. - СПб: СПбГУ ИТМО, 2009. - 50 с.

13. Solomon J. Numerical algorithms: methods for computer vision, machine learning, and graphics : textbook / J. Solomon. - USA : CRC Press (AK Peters, Ltd.), 2015. $400 \mathrm{p}$

14. Yang $X$. Optimization techniques and applications with examples / X. Yang. - USA, UK : WILEY, 2018. - 384 p.
15. Operations research applications / Eds.: G. Stecca. - Rome, Italy : AIRO (Associazone Italiana di Ricerca Operativa), 2017. - $123 \mathrm{p}$

16. Черноруцкий И. Г. Методы оптимизации в теории управления : учебное пособие / И. Г. Черноруцкий. СПб : Питер, 2004. - 256 c.

17. Information technology strategy 2018-21: annual report of progress planned GB.331-PFA-5-2018 / Eds. : Information and technology management department, Inernetional labour office. - Geneva, Switzerland : INFOTEC, ILO, 2017. $26 \mathrm{p}$.

18. Measuring the information society report 2018 / Eds.: International Telecommunication Union, Sanou B. Geneva, Switzerland : ITU Publications, 2018. Volume 1. $-204 \mathrm{p}$

19. Trends and advances in information systems and technologies : 2018 World conference on information systems and technologies WorldCIST'18, Naples, Italy, 27 29 March, 2018 : proceedings / Eds. : A. Rocha, H. Adeli, L. P. Reis, S. Costanzo. - Naples, Italy : Springers International Publishing, 2018. - Volume 3 (347). - 406 p.

20. Enterprise information systems : 20-th International conference ICEIS 2018, Funchal, Madeira, Portugal, 21-24 March, 2018 : proceedings / Eds. : S. Hammoudi, M. Smialek, O. Camp, J. Filipe. - Madeira, Portugal : SciTePress, Science Technology Publications, Lda, 2018. Volume 1. $-440 \mathrm{p}$.

21. Computer Science and Information Technology : Forth International conference CoSIT-2017, Geneva, Switzerland, 25-26 March, 2017 : proceedings / Eds. : D. Nagamalai, N. Meghanathan. - Geneva, Switzerland : AIRCC Publishing Corporation, 2017. - $208 \mathrm{p}$.

22. Антоненко В. М. Сучасні інформаційні системи i технології: управління знаннями : навчальний посібник / В.М.Антоненко, С. Д. Мамченко, Ю.В.Рогушина. Ірпінь : Національний університет ДПС України, 2016. $212 \mathrm{c}$.

23. Табунщик Г. В. Проектування, моделювання та аналіз інформаційних систем : навчальний посібник / Г.В.Табунщик, Р. К. Кудерметов, А. В. Притула. Запоріжжя : ЗНТУ, 2011. - 292 с.

24. Есипов Б. А. Методы оптимизации и исследования операций. Конспект лекций : учебное пособие / Б. А. Есипов. - Самара : Изд-во. Самар. аэрокосм. ун-та, 2007. $-180 \mathrm{c}$.

25. Інформаційні потоки та їх класифікація. - [Електронний pecypc. - Режим доступу: http://pidruchniki.com/68003/logistika/ informatsiyni potoki klasifikatsiya].

26. Девянин П. Н. Модели безопасности информационных потоков / П. Н. Девянин // Модели безопасности информационных систем : учебное пособие для студентов высших учебных заведений. - М. : «Академия», 2005. - 468 с. - С. 55-66.

27. Khodakov V. Ye. Models of training procedures V. Ye. Khodakov, A. Ye. Sokolov, G. V. Veselovskaya // Radio Electronics, Computer Science, Control. - 2018. № 4 (47). - P. 51-60. DOI: 10.15588/1607-3274-2018-4-5. 